\title{
Znaczenie oceny minimalnej choroby resztkowej w amyloidozie AL
}

\section{Significance of minimal residual disease evaluation in $\mathrm{AL}$ amyloidosis}

\author{
Agnieszka Krzywdzińska ${ }^{1}$, Iwona Solarska ${ }^{1}$, Bartosz Puła ${ }^{2}$, Krzysztof Jamroziak ${ }^{2}$ \\ ${ }^{1}$ Pracownia Immunofenotypowania, Zakład Diagnostyki Hematologicznej, \\ Instytut Hematologii i Transfuzjologii, Warszawa \\ ${ }^{2}$ Klinika Hematologii, Instytut Hematologii i Transfuzjologii, Warszawa
}

\begin{abstract}
Streszczenie
Amyloidoza tańcuchów lekkich (amyloidoza AL) jest choroba systemowa, w której dochodzi do uszkodzenia narzqdów wskutek akumulacji ztogów amyloidu powstatych w wyniku syntezy biatek prekursorowych amyloidu — monoklonalnych tańcuchów lekkich immunoglobulin — przez klonalne plazmocyty szpiku kostnego. Celem leczenia jest powstrzymanie produkcji amyloidogennych tańcuchów lekkich poprzez eradykacje klonu patologicznych plazmocytów, co w konsekwencji powinno prowadzić do stabilizacji, a czesto również poprawy funkcji zajetych narzadów. Skuteczność leczenia określaja dwie sktadowe - odpowiedź hematologiczna i narzqdowa. Mimo uzyskania catkowitej remisji hematologicznej, u czesści chorych nawet śladowa populacja klonalnych plazmocytów szpiku kostnego pozostała po leczeniu może produkować niewielkie ilości monoklonalnych immunoglobulin, prowadzac do dalszych uszkodzeń narzadowych. Plazmocyty te nie sq wykrywalne rutynowo stosowanymi metodami i określa sie je mianem minimalnej choroby resztkowej (MRD). Zwazywszy na wyniki dotychczas opublikowanych badan, jest prawdopodobne, ze ocena MRD za pomoca cytometrii stanie sie $w$ przysztości standardowym elementem oceny odpowiedzi na leczenie amyloidozy AL. W niniejszej pracy przedstawiono metodyke oraz wyniki najnowszych badan dotyczacych oceny MRD w amyloidozie $A L$.
\end{abstract}

Słowa kluczowe: amyloidoza, minimalna choroba resztkowa, cytometria przepływowa

Hematologia 2018; 9, 3: 196-201

\begin{abstract}
Light chain amyloidosis (AL amyloidosis) is a systemic disease leading to organ damage due to deposition of amyloid fibers arising from accumulation of amyloid precursors - monoclonal immunoglobulin light chains produced by clonal bone marrow plasmocytes. The aim of therapy of patients with amyloidosis AL is the inhibition of amyloidogenic immunoglobulin light chains production, what should result in stabilization or often even improvement of involved organs' function. Treatment effectiveness evaluation is based on hematological and organ response. Despite achievement of complete hematological remission, in some of the patients even a trace number of plasmocytes persisting following treatment may lead to production of low amount of monoclonal immunoglobulins capable of deepening organ damage. These plasmocytes remain undetectable to
\end{abstract}

Adres do korespondencji: Agnieszka Monika Krzywdzińska, Pracownia Immunofenotypowania, Zakład Diagnostyki Hematologicznej, Instytut Hematologii i Transfuzjologii, ul. Gandhi 14, 02-776 Warszawa, e-mail: akrzywdzinska@interia.pl 
routine diagnostic approaches and are regarded as minimal residual disease (MRD). Considering the results of the so far published research, it is possible that MRD assessment based on flow cytometric technique may constitute a basic tool of response assessment of AL amyloidosis treatment in the future. In this publication the methodology and results of latest research concerning MRD assessment in AL amyloidosis are presented.

\section{Key words: amyloidosis, minimal residual disease, flow cytometry}

Hematologia 2018; 9, 3: 196-201

\section{Wprowadzenie}

Amyloidoza łańcuchów lekkich (amyloidoza AL) jest chorobą systemową, w której dochodzi do uszkodzenia różnych narządów wskutek akumulacji złogów amyloidu powstałych w wyniku syntezy białek prekursorowych - monoklonalnych łańcuchów lekkich immunoglobulin (LC, light chains) - przez klonalne plazmocyty szpiku kostnego [1]. Stopień zajęcia szpiku przez klon plazmocytowy u większości chorych jest niewielki i wynosi średnio $10 \%$ komórek jądrzastych. Co istotne, badania cytomorfologiczne i immunohistochemiczne często nie umożliwiają precyzyjnej oceny wielkości klonu nowotworowego, ponieważ w szpiku kostnym u pacjentów $z$ amyloidozą $A L$ obserwuje się również istotny odsetek prawidłowych plazmocytów [2, 3]. $Z$ tego względu poszukuje się dodatkowych, bardziej wiarygodnych technik pozwalających na określenie wielkości nacieku plazmocytowego, szczególnie w fazie oceny odpowiedzi na zastosowaną terapię. Badania immunofenotypu komórek szpiku metodą cytometrii przepływowej (FC, flow cytometry) wykazały obecność aberrantnych komórek plazmatycznych (aPC, aberrant plasma cells) u $97 \%$ chorych $z$ amyloidozą AL [3]. O ich nowotworowym charakterze, podobnie jak w szpiczaku plazmocytowym (PCM, plasma cell myeloma) $\mathrm{i}$ innych gammapatiach monoklonalnych, świadczą zaburzenia ekspresji specyficznych antygenów błonowych oraz restrykcja jednego $z$ łańcuchów lekkich w cytoplazmie (kappa lub lambda). Analiza ekspresji pięciu antygenów, w tym CD38, CD138, CD19, CD45 i CD56, wystarcza, aby rozróżnić reaktywne i nowotworowe plazmocyty u około 90\% pacjentów $z$ dyskrazjami plazmocytowymi [4]. Specyficzność badania wzrasta do niemal $100 \%$, gdy w pełni wykorzysta się możliwości obecnie najczęściej stosowanej 8-kolorowej fluorocytometrii, dodając analizę ekspresji cytoplazmatycznych łańcuchów lekkich oraz dodatkowe trzy antygeny: CD27, CD81 i CD117 [4]. Dzięki możliwości analizy nawet kilku milionów komórek badanie cytometryczne charakteryzuje się bardzo wysoką czułością w wykrywaniu śladowych ilości aPC, która jest porównywalna $z$ technikami molekularnymi. Ponadto cytometryczna ocena wielkości klonu plazmocytów jest niezależna od ilości i rodzaju wydzielanego białka monoklonalnego, stopnia zajęcia tkanek i narządów przez złogi amyloidu, a także ilości produkowanych poliklonalnych immunoglobulin $[4,5]$.

W ostatnich latach FC znalazła zastosowanie $\mathrm{w}$ ocenie minimalnej choroby resztkowej (MRD, minimal residual disease) u pacjentów $z$ PCM. Powodem coraz większej popularności oceny MRD w PCM jest znacząca poprawa skuteczności nowych terapii. Powszechne stosowanie nowych, wysoce aktywnych schematów chemioterapii sprawiło, że standardowe metody oceny odpowiedzi na leczenie oparte na badaniach serologicznych przestały wystarczać. W licznych badaniach $\mathrm{z}$ zastosowaniem wieloparametrowej FC i technik molekularnych, amplifikacji allelospecyficznej reakcji łańcuchowej polimerazy (ASO-PCR, allele-specific oligonucleotide polymerase chain reaction) i sekwencjonowania następnej generacji (NGS, next generation sequencing), pozwalających na wykrywanie klonalnych plazmocytów $z$ czułością $10^{-4}-10^{-6}(0,01-0,0001 \%)$, wykazano, że jakość odpowiedzi istotnie koreluje ze wskaźnikami przeżycia chorych na PCM, niezależnie od rodzaju zastosowanej chemioterapii, stadium choroby czy wieku pacjenta [6, 7]. Ze względu na udowodnione znaczenie prognostyczne badanie MRD z czułością $10^{-5}$ włączono do kryteriów oceny odpowiedzi na terapię PCM rekomendowanych przez IMWG (International Myeloma Working Group). Ocena MRD stała się również wartościowym narzędziem w ocenie skuteczności najnowszych leków i schematów terapii [8]. Ponadto opracowano szczegółowe wytyczne dotyczące metodyki badania cytometrycznego, których zastosowanie może istotnie wspomóc proces standaryzacji między laboratoriami [9, 10]. Wysoka czułość i specyficzność, a także powszechna dostępność i relatywnie niski koszt badania decydują o tym, że cytometryczna ocena MRD w PCM jest coraz częściej stosowana w praktyce klinicznej, równiez w polskich ośrodkach hematologicznych [5]. 
O ile o znaczeniu immunofenotypowania w PCM świadczą publikacje już sprzed niemal 30 lat, o tyle pierwsza praca, w której oceniono prognostyczną wartość badania cytometrycznego szpiku kostnego u chorych $z$ amyloidozą AL, ukazała się dopiero w 2011 roku. Paiva i wsp. [11] analizowali znaczenie ilościowej oceny aPC w szpiku u 35 nowo zdiagnozowanych pacjentów $z$ amyloidozą AL. Wykazano, że niski odsetek aPC $\mathrm{w}$ aspiratach szpiku kostnego w momencie diagnozy $(<1 \%)$ istotnie koreluje $z$ dłuższym czasem przeżycia całkowitego (OS, overall survival) (2-letnie OS 90\% v. $44 \% ; \mathrm{p}=0,02)$. Podobnie korzystny wpływ na OS miała obecność prawidłowych plazmocytów. Grupa chorych, u których poliklonalne plazmocyty stanowiły ponad $5 \%$ całej populacji komórek plazmatycznych w szpiku, osiągali znacząco dłuższe przeżycie (2-letnie OS $88 \%$ v. 37\%; p =0,01). Podobną zależność zaobserwowali Muchtar i wsp. [12] w badaniu obejmującym 173 chorych. Odsetek aPC w okresie rozpoznania niższy od $2,5 \%$ korelował $z$ dłuższym czasem wolnym od progresji (PFS, progression-free survival) (2-letnie PFS $43 \%$ v. $27 \% ; \mathrm{p}=0,02)$ i OS (2-letnie OS $53 \%$ v. $36 \%$; $\mathrm{p}=0,01)$. Chorzy ci częściej również osiągali bardzo dobrą odpowiedź częściową (VGPR, very good partial response) po pierwszej linii leczenia. Co ciekawe, prognostyczne znaczenie wyjściowego stopnia zajęcia szpiku nie dotyczyło chorych poddanych chemioterapii wysokodawkowanej wspartej przeszczepieniem autologicznych krwiotwórczych komórek macierzystych (auto-HSCT, autologous hematopoietic stem cell transplantation) [12]. Według innych badaczy na przebieg choroby i skuteczność leczenia u poszczególnych chorych może również wpływać sam fenotyp komórek nowotworowych. Zauważono bowiem zależność między ekspresją molekuły CD56 a zajęciem mięśnia sercowego. $Z$ kolei pacjenci, u których patologiczne plazmocyty wykazywały ekspresję CD27 i CD81, rzadziej uzyskiwali bardzo dobrą odpowiedź na leczenie [13].

\section{Ocena minimalnej choroby resztkowej w amyloidozie AL}

Skuteczność leczenia w amyloidozie AL określają dwie składowe - odpowiedź hematologiczna i odpowiedź narządowa, odnosząca się do ewentualnej poprawy czynności zajętych narządów. Odpowiedź hematologiczna oznacza uzyskany w procesie leczenia stopień redukcji klonu nowotworowych plazmocytów. Obowiązujące kryteria odpowiedzi hematologicznej są oparte na badaniu stężenia białka monoklonalnego we krwi i moczu metodami elektroforezy i immunofiksacji oraz pomiarze stężenia wolnych łańcuchów lekkich w surowicy (kappa/lambda) (sFLC, serum free light chain) [14]. Odpowiedź hematologiczna obejmuje cztery kategorie służące stratyfikacji pacjentów do grup istotnie różniących się rokowaniem. Celem dzisiejszych terapii jest uzyskanie co najmniej VGPR. Ten stopień odpowiedzi wiąże się ze znaczącą poprawą rokowania, a prawdopodobieństwo remisji narządowej $\mathrm{u}$ chorych $\mathrm{z}$ VGPR ocenia się na 30-50\%. Całkowita remisja (CR, complete remission) jest definiowana jako normalizacja stosunku sFLC oraz negatywny wynik badania immunofiksacyjnego w surowicy i moczu. To obecnie najważniejszy wskaźnik skuteczności leczenia korelujący z dłuższym przeżyciem i poprawą funkcjonowania objętych chorobą narządów. Szacuje się, że niezależnie od zastosowanego schematu terapii u chorych w CR prawdopodobieństwo 5-letniego przeżycia wynosi około 70\% [15].

U większości chorych w CR w badaniu morfologicznym plazmocyty stanowią poniżej $5 \%$ komórek szpiku. W związku $\mathrm{z}$ brakiem istotnej wartości klinicznej badanie to nie jest uwzględnione w kryteriach odpowiedzi. Tymczasem nawet śladowa populacja klonalnych plazmocytów pozostałych po leczeniu może produkować niewielkie ilości monoklonalnych immunoglobulin. Nie są one wykrywalne rutynowo stosowanymi metodami, ale nadal mogą destrukcyjnie oddziaływać na tkanki. To właśnie niewielka pozostałość choroby, występującej poniżej poziomu wykrywalnego klinicznie rutynowymi metodami diagnostycznymi (badanie histopatologiczne oraz cytologiczne szpiku kostnego), może tłumaczyć opóźnioną odpowiedź narządową czy postępujące upośledzenie funkcji zajętych organów mimo osiągnięcia hematologicznej CR. Zważywszy na heterogenność schorzenia, stosunkowo często osiaggane hematologiczne CR i pojawiające się nowe opcje terapeutyczne, wzorowane na doświadczeniach w leczeniu PCM, również w przypadku amyloidozy AL, badanie MRD może być parametrem efektywności leczenia i istotnym wskaźnikiem prognostycznym [5].

Ostatnio pojawiło się kilka publikacji, w których oceniano znaczenie cytometrycznego badania MRD w szpiku chorych $z$ amyloidozą AL. W jednej Z nich wartość prognostyczną MRD badano u 82 chorych po zakończonym leczeniu pierwszej linii ( $84 \%$ po auto-HSCT, $16 \%$ po indukcji). Obecność MRD na poziomie $0,1 \%$ lub wyższym korelowała $z$ krótszymi PFS i OS $w$ porównaniu $z$ grupą pacjentów MRD-ujemnych $(<0,1 \%)$ (2-letnie PFS 
$31 \%$ v. $87 \%$; $\mathrm{p}<0,0001,2$-letnie OS $87 \%$ v. $98 \%$; $\mathrm{p}=0,02)$. Poziom MRD okazał się istotniejszy niż kryterium uzyskania VGPR. Grupę pacjentów, którzy uzyskali co najmniej VGPR, ale $z$ wykrytą MRD ponad $0,1 \%$, cechowało wyższe ryzyko progresji niż chorych $z$ MRD poniżej $0,1 \%$ ( $54 \% v$. $17 \%$; $\mathrm{p}=0,01)[12]$.

W krótkim doniesieniu na łamach czasopisma „Blood” Jimenez-Zepeda i wsp. [16] opisali wyniki badania, w którym cytometria posłużyła ocenie stopnia odpowiedzi na terapię według schematu CyBorD (cyklofosamid, bortezomib, deksametazon). Po medianie 5 cykli leczenia CR osiągnęło niemal $28 \%$ spośród 36 chorych włączonych do badania. Minimalną chorobę resztkową wykryto u połowy $z$ nich (5/10), co stanowiło około $14 \%$ badanej grupy. Mediana OS w grupach MRD-pozytywnej i -negatywnej była podobna, natomiast zaobserwowano trend do dłuższego PFS u chorych $\mathrm{z}$ ujemną MRD $(\mathrm{p}=0,06)$ [16].

Największą grupę chorych objęto retrospektywnym badaniem $z$ amerykańskiego ośrodka Mayo Clinic, w którym ocenę odpowiedzi przeprowadzono średnio po 100 dniach od auto-HSCT u 540 pacjentów $z$ amyloidozą AL [17]. Spośród 220 chorych w CR u 166 osób (75\%) nie stwierdzono obecności aPC w szpiku w badaniach morfologicznym, immunohistochemicznym i metodą FC. Ta grupa pacjentów, spełniając kryterium stosowanej w PCM rygorystycznej CR (sCR, stringent CR), osiągnęła znacząco dłuższe PFS (151 miesięcy w przypadku sCR $v$. 72 miesiące w przypadku CR; $\mathrm{p}=0,0003)$. Nie zaobserwowano natomiast różnic w odniesieniu do OS. Korzystny wpływ głębszej redukcji klonu PC nie zależał od rodzaju chemoterapii przed auto-HSCT, stadium zaawansowania według Mayo ani obecności t(11;14). Autorzy sugerują, że identyfikacja chorych obciążonych wyższym ryzykiem progresji może mieć istotną wartość kliniczną przy rozważaniu takich opcji, jak konsolidacja lub leczenie podtrzymujące po przeszczepieniu. Badanie to pozwoliło również na ocenę wpływu różnych czułości badania cytometrycznego. Okazało się bowiem, że tylko ocena MRD z czułością $10^{-4}$ i wyższą miała istotne znaczenie $\mathrm{w}$ odniesieniu do PFS [17].

Badanie MRD z progiem detekcji aPC w szpiku wynoszącym $10^{-5}(0,001 \%)$ wykorzystała grupa badaczy $z$ włoskiego Centrum Amyloidozy w Pavii [18]. Minimalną chorobę resztkową wykryto u 5 z 11 chorych spełniających kryteria CR, przy czym aPC stanowiły średnio 0,03\% komórek szpiku. $\mathrm{U}$ wszystkich badanych w momencie diagnozy stwierdzono zajęcie nerek, a u $6 \mathrm{z}$ nich dodatkowo serca. Analizowano zależność między odpowiedzią hematologiczną, MRD i odpowiedzią narządową. Zauważono, że osiagnięcie ujemnego statusu MRD nie zależało od rodzaju i stopnia zajęcia narządów przy rozpoznaniu, a także rodzaju terapii ani stopnia uzyskanej odpowiedzi narządowej w momencie stwierdzenia hematologicznej CR. Natomiast ujemny wynik oceny MRD był istotnie związany $z$ tendencją do poprawy funkcji tych organów $(\mathrm{p}=0,022)$ [18]. Zależność między statusem MRD a odpowiedzią narządową potwierdzono w doświadczeniach Sidana i wsp. [19], którzy zaobserwowali dłuższe PFS u chorych w CR z niewykrywalnymi aPC w szpiku.

Pojawiło się również pierwsze doniesienie o wynikach oceny MRD, w którym wykorzystano metodykę opartą na założeniach cytometrii nowej generacji (NGF, next generation flow) [20]. Jest ona zalecana w ostatnich rekomendacjach IMWG do określania głębokich odpowiedzi w PCM $z$ czułością co najmniej $10^{-5}$. Badanie objęło 20 chorych, u których stwierdzono CR oraz $5 z$ VGPR. Minimalną chorobę resztkową wykryto u wszystkich pacjentów $z$ VGPR oraz u 12 chorych z CR $(60 \%)$. Wysoka czułość oznaczenia $\left(10^{-5}-10^{-6}\right)$ umożliwiła wykrycie klonalnych plazmocytów także w 5 przypadkach, w których stanowity one mniej niż 0,003\% komórek szpiku. Nie stwierdzono obecności czynników wykazujących istotny wpływ na osiągnięcie statusu MRD-negatywnego, choć autorzy zwracają uwagę, że badaną grupę stanowili pacjenci cechujący się niskim i pośrednim ryzykiem. Niewielka liczebność grupy i krótki czas obserwacji nie pozwolity na obiektywną ocenę wpływu obecności MRD na odpowiedź narządową. Niemniej autorzy stawiają hipotezę, że brak MRD mógłby korzystnie wpływać na poprawę ze strony bardziej wrażliwych organów, takich jak serce, czy częstszą odpowiedź więcej niż jednego narządu. Zwracają również uwagę na stosunkowo wysoką częstość wykrywania MRD wśród pacjentów po auto-HSCT (2/8) [20].

Kolejnym obszarem zainteresowania badaczy, w którym wykorzystuje się FC, są tak zwane krążące plazmocyty we krwi obwodowej (cPC, circulating plasma cells). Wykazano dotychczas, że obecność klonalnych komórek plazmatycznych we krwi chorych, wykrywana metodą cytometryczną, stanowi niekorzystny czynnik rokowniczy zarówno u chorych na PCM, jak i na gammapatię monoklonalną o nieokreślonym znaczeniu (MGUS, monoclonal gammopathy of undetermined significance) [21-23]. W ostatnio opublikowanych wynikach badania Sidana i wsp. [23] wskazuje się na podobne 
znaczenie aPC w amyloidozie AL. W badaniu analizowano wyizolowane $z$ krwi komórki jednojądrzaste i zastosowano 6-kolorowy panel przeciwciał, a czułość badania wyniosła około $0,01 \%$. Krążące we krwi klonalne plazmocyty wykryto u 65 ze 154 badanych chorych (42\%). Obecność aPC była związana $Z$ większym $(\geq 10 \%)$ zajęciem szpiku, nie miała jednak istotnego wpływu na stopień odpowiedzi ani hematologicznej, ani narządowej osiągniętych po terapii. Wykazano natomiast negatywny wpływ na wskaźniki PFS i OS. Średnie PFS u chorych $z$ obecnymi aPC i bez obecności aPC przy rozpoznaniu wyniosły odpowiednio 31 miesięcy w porównaniu z 52 miesiącami $(\mathrm{p}=0,02)$, a OS -90 miesięcy $\mathrm{w}$ porównaniu z 98 miesiącami $(\mathrm{p}=0,003)$. Co ciekawe, zależności tej nie potwierdzono w grupie chorych, którzy po leczeniu osiągnęli co najmniej VGPR [23]. Jak podkreślają autorzy, niezbędne są kolejne badania służące określeniu wartości oceny tego parametru $\mathrm{u}$ chorych $\mathrm{z}$ amyloidozą. Może ono wspomóc proces leczniczy dzięki identyfikacji chorych $z$ grupy wyższego ryzyka, zwłaszcza wśród tych, którzy nie osiągnęli odpowiedzi hematologicznej.

\section{Podsumowanie}

Biorąc pod uwagę przytoczone publikacje można stwierdzić, $\dot{z}$ e cytometryczna ocena MRD o progu czułości co najmniej $10^{-4}$ pozwala na wykrycie patologicznych plazmocytów w szpiku u 40-60\% pacjentów z amyloidozą AL, którzy osiągnęli hematologiczną CR oraz u wszystkich z VGPR. Obecność MRD wiązała się $z$ dłuższym PFS we wszystkich analizowanych badaniach, ale tylko w jednym miała istotny wpływ na OS. Dotychczas opublikowane prace dotyczą zwykle niewielkich grup chorych, a liczba zmiennych parametrów charakteryzujących stan kliniczny poszczególnych pacjentów często utrudniała ocenę znaczenia stopnia eradykacji klonu plazmocytów dla późniejszego uzyskania odpowiedzi narządowej. W dwóch przytoczonych badaniach wskazuje się jedynie na tendencję do głębszej odpowiedzi zajętych narządów u chorych bez stwierdzonej MRD. Co interesujące, $w$ żadnej z publikacji nie znaleziono czynników o istotnym wpływie na obecność lub brak MRD. Sugeruje to, że - podobnie jak w PCM — poziom MRD w amyloidozie AL ma szansę stać się niezależnym wskaźnikiem prognostycznym.

Choć rola badania MRD w amyloidzie AL nie jest jeszcze w pełni poznana, a większość stawianych hipotez wymaga potwierdzenia, to nie ulega wątpliwości, że ocena MRD w amyloidzie będzie coraz częstszym przedmiotem badań. Być może, analogicznie jak w PCM, ocena MRD ma szansę stać się istotnym parametrem wspierającym proces leczniczy, w tym szczególnie ocenę skuteczności terapii i ryzyka nawrotu choroby.

\section{Piśmiennictwo}

1. Jamroziak K, Milani P, Puła B, et al. Diagnostyka i leczenie amyloidozy AL. Hematologia. 2018; 9(3): 181-196, doi: 10.5603/ /Hem.2018.0024.

2. Perfetti V, Colli Vignarelli M, Anesi E, et al. The degrees of plasma cell clonality and marrow infiltration adversely influence the prognosis of AL amyloidosis patients. Haematologica. 1999; 84(3): 218-221, indexed in Pubmed: 10189385.

3. Lisenko K, Schönland SO, Jauch A, et al. Flow cytometry-based characterization of underlying clonal $\mathrm{B}$ and plasma cells in patients with light chain amyloidosis. Cancer Med. 2016; 5(7): 1464 -1472, doi: 10.1002/cam4.725, indexed in Pubmed: 27109862.

4. Flores-Montero J, de Tute R, Paiva B, et al. Immunophenotype of normal vs. myeloma plasma cells: Toward antibody panel specifications for MRD detection in multiple myeloma. Cytometry B Clin Cytom. 2016; 90(1): 61-72, doi: 10.1002/cyto.b.21265, indexed in Pubmed: 26100534.

5. Jamroziak K, Krzywdzińska A, Solarska I, et al. Znaczenie minimalnej choroby resztkowej w szpiczaku plazmocytowym Stanowisko Polskiego Konsorcjum Szpiczakowego. Hematologia. 2017; 8(4): 246-254, doi: 10.5603/hem.2017.0036.

6. Landgren O, Devlin S, Boulad M, et al. Role of MRD status in relation to clinical outcomes in newly diagnosed multiple myeloma patients: a meta-analysis. Bone Marrow Transplant. 2016; 51(12): 1565-1568, doi: 10.1038/bmt.2016.222, indexed in Pubmed: 27595280.

7. Lahuerta JJ, Paiva B, Vidriales MB, et al. GEM (Grupo Español de Mieloma)/PETHEMA (Programa para el Estudio de la Terapéutica en Hemopatías Malignas) Cooperative Study Group. Depth of response in multiple myeloma: a pooled analysis of three PETHEMA/GEM clinical trials. J Clin Oncol. 2017; 35(25): 2900-2910, doi: 10.1200/JCO.2016.69.2517, indexed in Pubmed: 28498784.

8. Kumar S, Paiva B, Anderson KC, et al. International Myeloma Working Group consensus criteria for response and minimal residual disease assessment in multiple myeloma. Lancet Oncol. 2016; 17(8): e328-e346, doi: 10.1016/S1470-2045(16)30206-6, indexed in Pubmed: 27511158.

9. Oldaker TA, Wallace PK, Barnett D. Flow cytometry quality requirements for monitoring of minimal disease in plasma cell myeloma. Cytometry B Clin Cytom. 2016; 90(1): 40-46, doi: 10.1002/ /cyto.b.21276, indexed in Pubmed: 26201282.

10. Flores-Montero J, Sanoja-Flores L, Paiva B, et al. Next generation flow for highly sensitive and standardized detection of minimal residual disease in multiple myeloma. Leukemia. 2017; 31(10): 2094-2103, doi: 10.1038/leu.2017.29, indexed in Pubmed: 28104919.

11. Paiva B, Vídriales MB, Pérez JJ, et al. The clinical utility and prognostic value of multiparameter flow cytometry immunophenotyping in light-chain amyloidosis. Blood. 2011; 117(13): 3613-3616, doi: 10.1182/blood-2010-12-324665, indexed in Pubmed: 21266717.

12. Muchtar E, Jevremovic D, Dispenzieri A, et al. The prognostic value of multiparametric flow cytometry in $\mathrm{AL}$ amyloidosis at 
diagnosis and at the end of first-line treatment. Blood. 2017; 129(1): 82-87, doi: 10.1182/blood-2016-06-721878, indexed in Pubmed: 27729322.

13. Sachchithanantham S, Baginska A, Rowczenio D, et al. Use of plasma cell immunophenotype as prognostic markers in patients with systemic AL amyloidosis. Blood. 2013; 122(21): 3120-3120.

14. Palladini G, Dispenzieri A, Gertz MA, et al. New criteria for response to treatment in immunoglobulin light chain amyloidosis based on free light chain measurement and cardiac biomarkers: impact on survival outcomes. J Clin Oncol. 2012; 30(36): 4541-4549, doi: 10.1200/JCO.2011.37.7614, indexed in Pubmed: 23091105.

15. Dispenzieri A, Buadi F, Kumar SK, et al. Treatment of immunoglobulin light chain amyloidosis: Mayo Stratification of Myeloma and Risk-Adapted Therapy (mSMART) Consensus Statement. Mayo Clin Proc. 2015; 90(8): 1054-1081, doi: 10.1016/j.mayocp.2015.06.009, indexed in Pubmed: 26250727.

16. Jimenez-Zepeda V, Duggan $P$, Neri $P$, et al. Minimal residual disease (MRD) assessed by flow cytometry in patients with $\mathrm{AL}$ amyloidosis treated with cyclophosphamide, bortezomib and dexamethasone (CyBorD). Blood. 2017; 130(Suppl 1): 1836-1836.

17. Sidiqi MH, Aljama MA, Jevremovic D, et al. Prognostic significance of stringent complete response after stem cell transplantation in immunoglobulin light chain amyloidosis. Biol Blood Marrow Transplant. 2018 [Epub ahead of print], doi: 10.1016/j. bbmt.2018.06.027, indexed in Pubmed: 29964192.
18. Palladini G, Massa M, Basset M, et al. Persistence of minimal residual disease by multiparameter flow cytometry can hinder recovery of organ damage in patients with AL amyloidosis otherwise in complete response. Blood. 2016; 128(22): 3261-3261.

19. Sidana S, Tandon N, Dispenzieri A, et al. The importance of bone marrow examination in patients with light chain amyloidosis achieving a complete response. Leukemia. 2018; 32(5): 1243-1246, doi: 10.1038/s41375-018-0022-3, indexed in Pubmed: 29568089.

20. Kastritis E, Kostopoulos IV, Terpos E, et al. Evaluation of minimal residual disease using next-generation flow cytometry in patients with AL amyloidosis. Blood Cancer J. 2018; 8(5): 46, doi: 10.1038/ /s41408-018-0086-3, indexed in Pubmed: 29795385.

21. Gonsalves WI, Rajkumar SV, Dispenzieri A, et al. Quantification of circulating clonal plasma cells via multiparametric flow cytometry identifies patients with smoldering multiple myeloma at high risk of progression. Leukemia. 2017; 31(1): 130-135, doi: 10.1038/ /leu.2016.205, indexed in Pubmed: 27457702.

22. Gonsalves WI, Rajkumar SV, Gupta V, et al. Quantification of clonal circulating plasma cells in newly diagnosed multiple myeloma: implications for redefining high-risk myeloma. Leukemia. 2014; 28(10): 2060-2065, doi: 10.1038/leu.2014.98, indexed in Pubmed: 24618735.

23. Sidana S, Tandon N, Dispenzieri A, et al. Prognostic significance of circulating plasma cells by multi-parametric flow cytometry in light chain amyloidosis. Leukemia. 2018; 32(6): 1421-1426, doi: 10.1038/s41375-018-0063-7, indexed in Pubmed: 29483709. 